\title{
New Transmembrane AMPA Receptor Regulatory Protein Isoform, $\gamma$-7, Differentially Regulates AMPA Receptors
}

\author{
Akihiko S. Kato, ${ }^{1}$ Wei Zhou, ${ }^{3}$ Aaron D. Milstein, ${ }^{3}$ Mike D. Knierman, ${ }^{2}$ Edward R. Siuda, ${ }^{1}$ Joe E. Dotzlaf, ${ }^{2}$ Hong Yu, ${ }^{1}$ \\ John E. Hale, ${ }^{2}$ Eric S. Nisenbaum, ${ }^{1}$ Roger A. Nicoll, ${ }^{3}$ and David S. Bredt ${ }^{1,2}$ \\ ${ }^{1}$ Neuroscience Discovery and ${ }^{2}$ Integrated Biology, Lilly Research Laboratories, ${ }^{3}$ Departments of Physiology, and Cellular and Molecular Pharmacology, \\ University of California, San Francisco, San Francisco, California 94143
}

\begin{abstract}
AMPA-type glutamate receptors (GluRs) mediate most excitatory signaling in the brain and are composed of GluR principal subunits and transmembrane AMPA receptor regulatory protein (TARP) auxiliary subunits. Previous studies identified four mammalian TARPs, $\gamma$ - 2 (or stargazin), $\gamma-3, \gamma-4$, and $\gamma-8$, that control AMPA receptor trafficking, gating, and pharmacology. Here, we explore roles for the homologous $\gamma-5$ and $\gamma-7$ proteins, which were previously suggested not to serve as TARPs. Western blotting reveals high levels of $\gamma-5$ and $\gamma-7$ in the cerebellum, where $\gamma-7$ is enriched in Purkinje neurons in the molecular layer and glomerular synapses in the granule cell layer. Immunoprecipitation proteomics shows that cerebellar $\gamma-7$ avidly and selectively binds to AMPA receptor GluR subunits and also binds to the AMPA receptor clustering protein, postsynaptic density-95 (PSD-95). Furthermore, $\gamma$-7 occurs together with PSD-95 and AMPA receptor subunits in purified postsynaptic densities. In heterologous cells, $\gamma$-7 but not $\gamma$-5 greatly enhances AMPA receptor glutamateevoked currents and modulates channel gating. In granule cells from stargazer mice, transfection of $\gamma$-7 but not $\gamma$-5 increases AMPA receptor-mediated currents. Compared with stargazin, $\gamma-7$ differentially modulates AMPA receptor glutamate affinity and kainate efficacy. These studies define $\gamma-7$ as a new member of the TARP family that can differentially influence AMPA receptors in cerebellar neurons.
\end{abstract}

Key words: glutamate receptor; mass spectroscopy; auxiliary subunit; ion channel; cerebellum; excitatory amino acid

\section{Introduction}

AMPA-type glutamate receptors (GluRs) are selective cation channels, whose activation produces the postsynaptic depolarization that induces neuronal firing. AMPA receptors occur in all central neurons and exist as heterotetramers formed from subunits GluR1-4 (Seeburg, 1993; Hollmann and Heinemann, 1994). Various combinations of GluR subunits and their alternatively spliced "flip" and "flop" isoforms are expressed in distinct neuronal populations and confer differential AMPA receptor functional properties (Sommer et al., 1990).

In addition to the GluR subunits, neuronal AMPA receptors also contain transmembrane AMPA receptor regulatory proteins (TARPs) (Nicoll et al., 2006). The prototypical TARP, stargazin $(\gamma-2)$, is mutated in stargazer mice, which display absence epilepsy and cerebellar ataxia (Noebels et al., 1990). Granule cells from stargazer mice lack functional AMPA receptors (Chen et al., 1999; Hashimoto et al., 1999). Biochemical and cell biological studies demonstrate that stargazin, a four-pass transmembrane protein (Letts et al., 1998), plays an essential role in surface trafficking and synaptic targeting of AMPA receptors (Chen et al.,

Received Dec. 21, 2006; revised March 7, 2007; accepted March 29, 2007.

R.A.N. was supported by the National Institutes of Health. A.M. was supported by a National Science Foundation graduate research fellowship.

Correspondence should be addressed to David S. Bredt, Integrative Biology, Lilly Research Laboratories, Eli Lilly and Company, Indianapolis, IN 46285-0510. E-mail: bredt@lilly.com.

DOI:10.1523/JNEUROSCI.5561-06.2007

Copyright $\odot 2007$ Society for Neuroscience $\quad$ 0270-6474/07/274969-09\$15.00/0
2000). Stargazin directly binds to AMPA receptors and escorts them to the cell surface (Chen et al., 2000; Nakagawa et al., 2005; Vandenberghe et al., 2005). The C-terminal tail of stargazin associates with postsynaptic density-95 (PSD-95) and related membrane-associated guanylate kinase proteins, which cluster AMPA receptors at synapses (El-Husseini et al., 2000; Schnell et al., 2002; Elias et al., 2006) The first extracellular loop of stargazin associates with the glutamate-binding module in AMPA receptors (Tomita et al., 2006b) and thereby modulates channel gating and pharmacology (Yamazaki et al., 2004; Turetsky et al., 2005; Bedoukian et al., 2006; Tomita et al., 2006a). Stargazin delays deactivation and desensitization of AMPA receptors (Priel et al., 2005; Tomita et al., 2005b), enhances the action of kainate on AMPA receptors (Tomita et al., 2005b; Turetsky et al., 2005), and modulates the effects of AMPA receptor potentiators, such as cyclothiazide (Tomita et al., 2006a; Zhang et al., 2006). Phosphorylation of stargazin regulates AMPA receptors in synaptic plasticity (Tomita et al., 2005a).

The AMPA receptor defect in stargazer mice manifests only in cerebellar granule cells (Chen et al., 1999; Hashimoto et al., 1999), which can be explained by widespread neuronal expression of three additional TARP isoforms $(\gamma-3, \gamma-4$, and $\gamma$-8) (Tomita et al., 2003). The crucial role for TARP isoforms in the forebrain is exemplified by the phenotype of $\gamma$ - 8 knock-out mice (Rouach et al., 2005; Fukaya et al., 2006). The $\gamma-8$ protein is expressed at highest levels in hippocampal pyramidal neurons, which show profound defects in AMPA receptor trafficking and 
function in $\gamma-8$ knock-out (Rouach et al., 2005; Fukaya et al., 2006).

In addition to the four identified TARPs, the mammalian genome contains several additional genes related to stargazin (Klugbauer et al., 2000; Burgess et al., 2001; Chu et al., 2001) that were named based on their similarity to the $\gamma$ - 1 calcium channel subunit from skeletal muscle. As opposed to the well studied TARPs $(\gamma-2, \gamma-3, \gamma-4, \gamma-8)$, much less is known of the other homologous genes, $\gamma-5, \gamma-6$, and $\gamma-7$. Previous studies showed that $\gamma-5$ does not modulate AMPA receptor function in oocytes (Tomita et al., 2004). And, a preliminary characterization suggested that $\gamma-7$ can inhibit the expression of calcium channels in oocytes or transfected cells (Moss et al., 2002). Here, we explored functional roles for $\gamma-5$ and $\gamma-7$ proteins, which unexpectedly define $\gamma-7$ as a new member of the TARP family that differentially regulates AMPA receptors.

\section{Materials and Methods}

Antibodies. The following commercially acquired antibodies were used: rabbit polyclonals to GluR1 (AB1504; Millipore, Bedford, MA), GluR2/3 (AB1506; Millipore), $\gamma$-2/3/4/8 (07-577; Millipore) and mouse monoclonals PSD-95 (MA1-046; Affinity Bioreagents, Golden, CO). Polyclonal antisera to $\gamma-5$ and $\gamma-7$ were raised by injecting rabbits with KLHconjugated peptides as follows: $\gamma-5$, CSDASLQMNSNYPALLK; and $\gamma-7$, CSIQMTQNYPPAIKYPDHLH. Antisera were affinity purified on agarose columns containing the immunizing antigen.

Immunoprecipitation. Ten rat cerebella or two rat cerebral cortices were homogenized with threefold tissue volume of buffer I $(0.32 \mathrm{M} \mathrm{su}-$ crose, 3 mM HEPES-Na, pH 7.4, 0.1 mg/ml PMSF) and spun at 20,000 $\times$ $g$ for $10 \mathrm{~min}$ at $4^{\circ} \mathrm{C}$. The resulting pellets were homogenized with 20 -fold the original tissue volume of buffer I and then solubilized with $0.1 \%$ Triton X-100 for $1 \mathrm{~h}$. After centrifugation at $100,000 \times g$ for $1 \mathrm{~h}$, the soluble extracts were precleared by the addition of protein A-Sepharose (GE Healthcare, Little Chalfont, UK). This supernatant was incubated with appropriate antibodies and then with $15 \mu$ l of protein A-Sepharose for $1 \mathrm{~h}$. The resultant resin was washed eight times with buffer I containing $20 \mathrm{~mm} \mathrm{NaCl}$. Adherent proteins were eluted with Laemmli sample buffer with $3 \% \mathrm{SDS}$ at $55^{\circ} \mathrm{C}$ for $30 \mathrm{~min}$ and then $95^{\circ} \mathrm{C}$ for $10 \mathrm{~min}$ and separated by SDS-PAGE.

cDNAs were introduced into 293T cells using Fugene 6. Cells were homogenized in buffer I $48 \mathrm{~h}$ after transfection and centrifuged at $37,000 \times g$. The resultant pellet was solubilized in radioimmunoprecipitation assay buffer $(20 \mathrm{~mm}$ Tris- $\mathrm{Cl}, 150 \mathrm{~mm} \mathrm{NaCl}, 0.5 \%$ sodium deoxycholate, $1 \%$ NP-40, $0.1 \%$ SDS) for $1 \mathrm{~h}$. After centrifugation at $100,000 \times$ $g$, solubilized lysates were immunoprecipitated with $2 \mu \mathrm{g}$ of anti-PSD-95 antibody and protein A/G Sepharose.

Mass spectrometry. Polyacrylamide gels were stained by silver as described previously (Shevchenko et al., 1996). The protein band migrating at $100 \mathrm{kDa}$ was excised and destained with $1 \% \mathrm{H}_{2} \mathrm{O}_{2}$ (Sumner et al., 2002). The gel pieces were reduced and alkylated as described previously (Hale et al., 2004). The in-gel proteins were digested with trypsin (20 $\mu \mathrm{g} / \mathrm{ml}$ ) overnight at $37^{\circ} \mathrm{C}$. The extracted peptides were purified with a Ziptip (C-18) (Millipore), and loaded onto an HPLC (HP 1100 Nanopump) with a reverse phase C-18 column connected to a mass spectrometer (LTQ-FT; ThermoFinnigan, Palo Alto, CA).

Electrophysiology. cDNAs for GluR1 (160 ng), TARP cDNA (40 ng), pEGFP-N3 (300 ng), and pcDNA3 (500 ng) were transfected into 293T $\left(1 \times 10^{6}\right.$ cell per $35 \mathrm{~mm}$ dish) using Fugene 6 (Roche, Mannheim, Germany). The cells were trypsinized $1 \mathrm{~d}$ after transfection and seeded on collagen-coated coverslips. Electrophysiological recording was performed after over-night incubation. Cells were transferred to the stage of an inverted microscope and bathed in a chamber with external buffer containing the following (in mM): $120.0 \mathrm{NaCl}, 5.0 \mathrm{BaCl}_{2}, 1.0 \mathrm{MgCl}_{2}, 20.0$ $\mathrm{CsCl}, 10.0$ glucose, 10.0 HEPES, $\mathrm{pH}=7.4 \pm 0.03$. Patch-clamp recordings were made in the whole-cell configuration from single green fluorescent protein (GFP)-positive cells at room temperature using Axopatch 200B. Membrane potential was held at $-80 \mathrm{mV}$. Pipette solution contained the following (in $\mathrm{mm}$ ): $160.0 \mathrm{~N}$-methyl-D-glucamine, 4.0 $\mathrm{MgCl}_{2}, 40.0$ HEPES, 12.0 phosphocreatine, $2.0 \mathrm{Na}_{2} \mathrm{ATP}, 0.2 \mathrm{GTP}, \mathrm{pH}=$ $7.2 \pm 0.02$. Application of solutions was accomplished with a sixteenbarrel pipette array made from small diameter (600 $\mu \mathrm{M}$ square internal diameter) glass capillary tubing (VitroCom, Mountain Lakes, NJ). Solutions were placed in $10 \mathrm{ml}$ syringes and positioned $\sim 30 \mathrm{~cm}$ above the recording chamber. Flow from each syringe was gravity dependent, and electronic valves were used to start and stop solution flow. The pipette array was positioned $100-200 \mu \mathrm{m}$ from the cell. The sixteen-barrel pipette array was moved with a DC actuator and a motion controller/driver (Newport, Irvine, CA).

Primary cultures of granule neurons were prepared from postnatal day $7 \mathrm{stg} / \mathrm{stg}$ mouse cerebella and plated at a density of $2.5 \times 10^{5} \mathrm{cells} / \mathrm{cm}^{2}$ on coverslips precoated with poly-D-lysine in 24-well dishes (BD Biosciences, Franklin Lakes, NJ). Cultures were maintained in a BME-based medium containing $25 \mathrm{~mm} \mathrm{KCl}, 10 \%$ FBS, 2 mm L-Glutamine, 2\% B27, and $60 \mu \mathrm{g} / \mathrm{ml}$ gentamicin [all from Invitrogen (San Diego, CA)] until $3 \mathrm{~d}$ in vitro (DIV) when the medium was replaced with a MEM-based medium (Invitrogen) containing $5 \mathrm{~mm} \mathrm{KCl}$ and supplemented with $5 \mathrm{mg} / \mathrm{ml}$ D-glucose (Sigma, St. Louis, MO), 2 mm L-glutamine (Invitrogen), 1\% insulin-transferrin-sodium selenite (Sigma), $20 \mu \mathrm{g} / \mathrm{ml}$ gentamicin (Invitrogen), and $4 \mu \mathrm{M}$ cytosine $\beta$-D-arabinofuranoside hydrochloride. Each coverslip was transfected with $1 \mu \mathrm{g}$ cDNA on 4 DIV with calcium phosphate (Losi et al., 2003). Whole-cell patch-clamp recordings were made 8-10 DIV in an extracellular solution containing the following: 145 mм NaCl, $5 \mathrm{~mm} \mathrm{KCl}, 1 \mathrm{~mm} \mathrm{CaCl}_{2}, 1 \mathrm{~mm} \mathrm{MgCl}_{2}, 5 \mathrm{~mm}$ D-glucose, $25 \mathrm{~mm}$ sucrose, $5 \mathrm{~mm}$ HEPES, $100 \mu \mathrm{m}$ picrotoxin (all from Sigma), $100 \mu \mathrm{M}$ $\mathrm{D}-\mathrm{APV}$ (Tocris, Ellisville, MO), and $1 \mu \mathrm{M}$ tetrodotoxin citrate (Tocris), $\mathrm{pH} 7.3$, using an internal pipette solution containing the following (in mM): $140 \mathrm{CsCl}, 2 \mathrm{MgCl}_{2}, 5$ EGTA, 10 HEPES, $0.3 \mathrm{NaGTP}$, and $4 \mathrm{Na}_{2} \mathrm{ATP}$, $\mathrm{pH}$ 7.3. Agonists were applied via a local perfusion barrel using a system acquired from Automate Scientific (San Francisco, CA).

HEK293T cells were plated at a density of $14,000-29,000 \mathrm{cells} / \mathrm{cm}^{2}$ onto glass coverslips coated with poly-D-lysine (Sigma) and collagen (Sigma) in 24-well plates. cDNAs for GluR1 (200 ng) and either enhanced GFP (EGFP) or TARP (300 ng) were transfected using Lipofectamine 2000. Patch-clamp recordings were performed $24-72 \mathrm{~h}$ after transfection at room temperature. A bicarbonate-buffered external solution was bubbled with $5 \% \mathrm{CO}_{2}$ and $95 \% \mathrm{O}_{2}$ and was perfused at $3 \mathrm{ml} /$ min. Glutamate $(1 \mathrm{~mm})$ was dissolved in a HEPES-buffered solution containing the following (in $\mathrm{mM}$ ): $150 \mathrm{NaCl}, 3 \mathrm{KCl}, 2 \mathrm{CaCl}_{2}, 1 \mathrm{MgCl}_{2}, 5$ glucose and 10 HEPES, $\mathrm{pH}$ 7.4, and applied using a theta pipette driven by a piezoelectric bimorph, as described previously (Tong and Jahr, 1994). The speed of application was confirmed by measuring the $20-$ $80 \%$ rise time of an open tip response, which was typically $<200 \mu$ s. Patch pipettes $(\sim 5 \mathrm{M} \Omega)$ were filled with an internal solution containing the following (in mM): $135 \mathrm{CsF}, 33 \mathrm{CsOH}, 2 \mathrm{MgCl}_{2}, 1 \mathrm{CaCl}_{2}, 0.1$ spermine, and 11 EGTA, pH 7.4. The time courses of decay were calculated by measuring the area under the peak-normalized response for 20 or $60 \mathrm{~ms}$ after the peak for deactivation and desensitization, respectively.

Immunohistochemistry. Fixation of rat brains were performed as described previously (Rouach et al., 2005; Fukaya et al., 2006). Sagittal sections $(40 \mu \mathrm{m})$ were cut with a cryostat and were then treated with $1 \%$ $\mathrm{H}_{2} \mathrm{O}_{2}$ in PBS for 20 min. The sections were treated with $3 \%$ normal goat serum plus $0.1 \%$ Triton $\mathrm{X}-100$ in PBS followed by incubation with the primary antibodies, $\gamma-7(0.3 \mu \mathrm{g} / \mathrm{ml}), \gamma-2 / 3 / 4 / 8(1 \mu \mathrm{g} / \mathrm{ml})$, GluR1 $(0.1$ $\mu \mathrm{g} / \mathrm{ml})$, and GluR2/3 $(0.1 \mu \mathrm{g} / \mathrm{ml})$. The sections were processed with Vectastain ABC Elite kit using DAB (3, 3' -diaminobenzidine).

Subcellular fractionation. Subcellular fractions were prepared by differential centrifugation as described previously (Jo et al., 1999). Ten rat cerebella were homogenized in $15 \mathrm{ml}$ of buffer I ( $0.32 \mathrm{M}$ sucrose, $3 \mathrm{~mm}$ HEPES-Na, pH 7.4, $0.1 \mathrm{mg} / \mathrm{ml}$ PMSF). The homogenate was centrifuged at $1000 \times g$ to produce a pellet (P1) and a supernatant (S1). The P1 pellet was resuspended in buffer I and centrifuged at $1000 \times g$ to obtain a crude nuclear fraction $\left(\mathrm{P}^{\prime}\right)$ and a supernatant $\left(\mathrm{S}^{\prime}\right)$. The combined superna$\operatorname{tant}\left(\mathrm{S} 1\right.$ plus $\left.\mathrm{S}^{\prime}{ }^{\prime}\right)$ was centrifuged at $12,000 \times \mathrm{g}$ for $15 \mathrm{~min}$ to produce a pellet (P2) and supernatant (S2). The S2 fraction was centrifuged at $33,000 \times g$ for 20 min to give a pellet (P3) and a supernatant (S3). The S3 fraction was centrifuged at $260,000 \times g$ for $2 \mathrm{~h}$ to produce a pellet $(\mathrm{P} 4)$ 


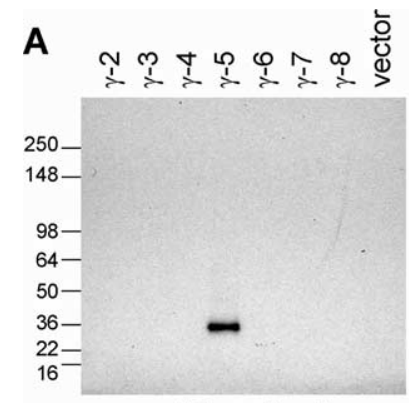

IB: anti- $\gamma-5$
B

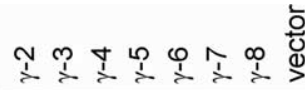

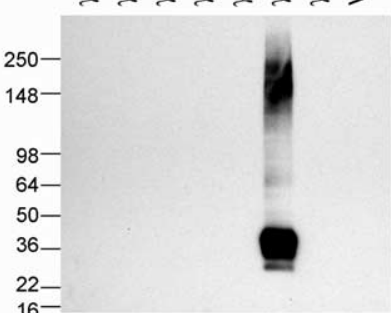

IB: anti- $\gamma-7$
C

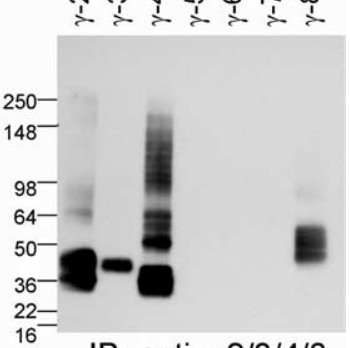

IB: anti- $\gamma-2 / 3 / 4 / 8$
D

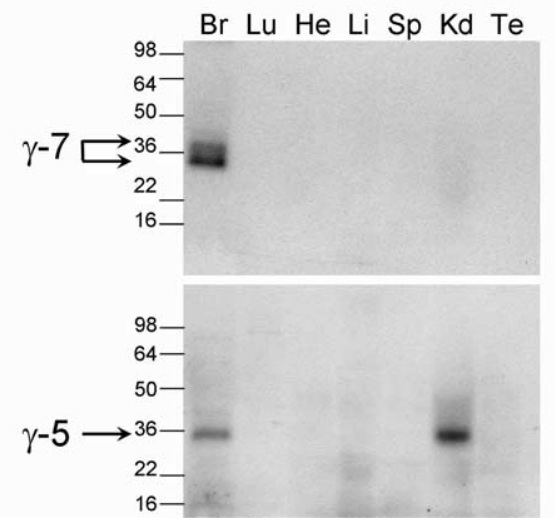

E
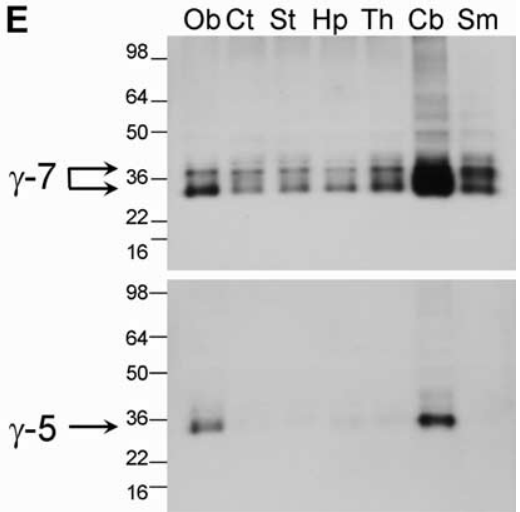

Figure 1. $\quad \gamma-5$ and $\gamma-7$ are enriched in cerebellum. $A-C$, Specificity of anti- $\gamma-5$ and $\gamma-7$ antibodies. Extracts from HEK 293T cells transiently transfected with cDNAs encoding $\gamma$ subunits were separated by SDS-PAGE and immunoblotted with antibodies to $\gamma-5$, $\gamma-7$, and $\gamma-2 . A, B$, The $\gamma-5$ and $\gamma-7$ antibodies label only their appropriate protein product. $C$, The anti- $\gamma-2$ antibody cross-reacts with $\gamma-3, \gamma-4$, and $\gamma-8$. IB, Immunoblotting. D, Tissue distribution of $\gamma-5$ and $\gamma-7$. Postnuclear membrane fractions $(5 \mu \mathrm{g})$ were blotted with antibodies as indicated. $\gamma-5$ was detected in the brain and kidney. $\gamma-7$ was detected only in the brain. Br, Brain; $\mathrm{Lu}$, lung; He, heart; Li, liver; Sp, spleen; Kd, kidney; Te, testis. E, Expression profile of $\gamma-5$ and $\gamma-7$ in the rat brain. $\gamma-5$ and $\gamma-7$ proteins were enriched in the cerebellum and also occur in the olfactory bulb. In addition, $\gamma-7$ occurs at low levels in all other brain regions surveyed. Postnuclear membrane fractions $(9 \mu \mathrm{g})$ were immunoblotted. $\mathrm{Ob}$, Olfactory bulb; $\mathrm{Ct}$, cerebral cortex; $\mathrm{St}$, striatum; $\mathrm{Hp}$, hippocampus; Th, Thalamus; Cb, cerebellum; Sm, brainstem.

and a supernatant ( 44 , cytosolic fraction). The P2 pellet was resuspended in the original volume of buffer I and centrifuged for $15 \mathrm{~min}$ at 13,000 $\times$ $g$ to yield the crude synaptosomal fraction $\left(\mathrm{P} 2^{\prime}\right)$. The P2' fraction was resuspended in homogenization buffer and hypotonically lysed by addition of 9 vol of ice-cold water with 4 mM HEPES, $\mathrm{pH} 7.4$, and incubated for $1 \mathrm{~h}$. The lysate was centrifuged for $20 \mathrm{~min}$ at $33,000 \times g$ to produce the lysate heavy membrane pellet (LP1) and lysate supernatant (LS1). The LS1 fraction was then centrifuged for $20 \mathrm{~min}$ at $260,000 \times g$ for $2 \mathrm{~h}$ to give a crude synaptosomal vesicle pellet (LP2) and a cytosolic synaptosomal supernatant (LS2). In a separate procedure, synaptosomes and PSD fractions were prepared from 10 rat cerebella. The synaptosome fraction was purified by discontinuous sucrose density gradient centrifugation and was extracted once or twice with ice-cold $0.5 \%$ Triton X-100 in $6 \mathrm{~mm}$ Tris-Cl, $\mathrm{pH} 7.5$, and then centrifuged to obtain the PSD I and PSD II pellets.

Solubility assay. Rat cerebella were homogenated in three tissue volumes of buffer I (0.32 M sucrose, $3 \mathrm{~mm}$ HEPES-Na, pH 7.4, $0.1 \mathrm{mg} / \mathrm{ml}$ PMSF) and centrifuged at 20,000 $\times g$. The resultant pellet was suspended in three times the original tissue volume of buffer I and solubilized with Triton X-100 for $1 \mathrm{~h}$ at $4^{\circ} \mathrm{C}$. The solubilized mixture was centrifuged at $100,000 \times g$, and the resultant supernatant and pellet were subjected to immunoblotting.

\section{Results}

\section{$\gamma-5$ and $\gamma-7$ are enriched in the cerebellum}

To understand functions for $\gamma-5$ and $\gamma-7$, we first generated antibodies directed against unique peptide sequences in the C-terminal tails of the proteins. After affinity purification, we evaluated antibody specificity by performing Western blotting on crude extracts from human embryonic kidney (HEK) cells trans-

fected with each $\gamma$ subunit. These experiments showed that our antibodies to $\gamma-5$ and $\gamma-7$ robustly recognize their appropriate $\gamma$ isoform and do not cross-react with other $\gamma$ subunits (Fig. 1A,B). An antibody raised to the $\mathrm{C}$ terminus of $\gamma-2$ crossreacts with $\gamma-3, \gamma-4$, and $\gamma-8$ (Fig. 1C).

Western blotting showed that our affinity purified antibodies for $\gamma-5$ and $\gamma-7$ recognize specific bands in membraneenriched fractions (Fig. 1D). These bands run at $\sim 35 \mathrm{kDa}$, which corresponds to the migration of $\gamma-5$ and $\gamma-7$ in transfected HEK cells. The immunoreactive $\gamma-7$ protein band occurs only in the brain and is not present in a variety of peripheral tissues (Fig. 1D). A previous reverse transcription PCR experiment detected $\gamma-7$ mRNA in the lung and testis as well (Chu et al., 2001), but this was below our detection by Western blotting. The $\gamma-5$ immunoreactive band occurs both in brain and in kidney extracts (Fig. 1D). Within the brain, both $\gamma-5$ and $\gamma-7$ are highly enriched in the cerebellum and occur at lower levels in the olfactory bulb (Fig. 1E). Low levels of $\gamma-7$ but not $\gamma-5$ also occur in the cerebral cortex, corpus striatum, hippocampus, thalamus, and brainstem (Fig. 1E).

\section{$\gamma-7$ selectively binds to neuronal AMPA receptors}

To identify protein interactions with $\gamma-5$ and $\gamma$-7, we conducted preparative immunoprecipitations. Rat cerebellar membranes were solubilized with Triton X-100 and were immunoprecipitated with antibodies to $\gamma-5$ and $\gamma$-7. Immunoprecipitates were extensively washed with buffer containing $20 \mathrm{~mm} \mathrm{NaCl}$. Tightly adherent proteins were eluted with 3\% SDS and then were separated by PAGE. Gels were stained with silver to identify all protein bands copurifying with $\gamma-5$ or $\gamma-7$. As controls, we performed immunoprecipitations with preimmune serum and did immunoprecipitations from a solubilized cerebral cortex, which expresses much less $\gamma-5$ and $\gamma-7$ than does the cerebellum. We did not detect clear protein bands coimmunoprecipitating with $\gamma-5$ (Fig. $2 A)$. However, we saw a prominent protein band of $\sim 100 \mathrm{kDa}$ associating with $\gamma-7$ in the cerebellar immunoprecipitates that was not apparent in cerebral cortex immunoprecipitates (Fig. $2 B$ ). Mass spectroscopic analysis of the $\sim 100 \mathrm{kDa} \gamma-7$ associated band showed that it contained peptides from AMPA receptor subunits GluR-1, $-2,-3$, and -4 (Table 1).

We explored the specificity for $\gamma-7$ interaction with AMPA receptor subunits by Western blotting. As reported previously (Tomita et al., 2004), GluR1 and GluR2/3 coimmunoprecipitated with $\gamma-2 / 3 / 4 / 8$ in solubilized membranes from the cerebellum or cerebral cortex. In the cerebellum, GluR1, and to a lesser extent GluR2/3, coimmunoprecipitated with $\gamma-7$ (Fig. 2C). We found weak coimmunoprecipitation of AMPA receptors with $\gamma-7$ in the cerebral cortex, which fits with the low expression of $\gamma-7$ in the cortex (Fig. 2C). In cerebellar extracts, we found a weak interaction of $\gamma-5$ with GluR1 (Fig. 2C). As this association of GluR1 with $\gamma-5$ did not occur in cerebrocortical extracts, it seems spe- 
cific. Overall, the immunoprecipitation of $\gamma-5$ was less robust than $\gamma-7$, which likely indicates our $\gamma-5$ antibody has lower avidity.

We detected little interaction between the TARP isoforms. That is, neither $\gamma-5$ nor $\gamma-2 / 3 / 4 / 8$ was detected in $\gamma$-7 immunoprecipitates, and neither $\gamma-7$ nor $\gamma-2 / 3 /$ $4 / 8$ was in $\gamma-5$ immunoprecipitates (Fig. $2 C)$. A very small amount of $\gamma-2 / 3 / 4 / 8$ was detected in the $\gamma-7$ immunoprecipitates (Fig. 2C). The lack of significant interaction among TARP isoforms suggests that $\gamma$-7 interaction with AMPA receptors does not require $\gamma-2 / 3 / 4 / 8$ as an intermediary.

\section{$\gamma-7$ is a novel TARP}

To determine whether $\gamma-7, \gamma-5$, and $\gamma-6$ control AMPA receptor function, we transfected HEK cells and quantified glutamate-evoked currents. In cells transfected with GluR1-flip (GluR1i), glutamate application generates a sharp inward current that rapidly desensitizes to a steady-state current of $\sim 45 \mathrm{pA}$. As reported previously (Chen et al., 2003), $\gamma$-2 greatly increases the glutamate-evoked response from GluR1i and yielded a steady state current of $\sim 400$ pA. (Fig. $3 A, B)$. Similarly, we found that $\gamma-7$ also greatly enhanced glutamate-evoked steady-state currents $(\sim 425 \mathrm{pA})$ (Fig. $3 A, B)$. Cells coexpressing $\gamma-7$ consistently showed slower kinetics in reaching steady-state current (Fig. $3 A$ ), and the mechanism for these distinct kinetics remains uncertain. $\gamma-5$ and $\gamma-6$ have no significant effect on the GluRli currents evoked by glutamate. The GluR1-flop (GluR1o) isoform yields glutamate-evoked current of only $\sim 1.25 \mathrm{pA}$, and this was enhanced 20 - or 10 -fold by cotransfection with $\gamma-2$ or $\gamma$-7, respectively (Fig. $3 C$ ).

The neurotoxin kainate produces large nondesensitizing currents through neuronal AMPA receptors (Kiskin et al., 1986; Jonas and Sakmann, 1992). However, in heterologous cells expressing GluR1i alone, kainate evoked a nondesensitizing current of only $\sim 35$ pA (Fig. $3 A, D$ ). As reported previously (Tomita et al., 2005b), $\gamma$-2 dramatically increases the steady-state currents to kainate, to $\sim 8000 \mathrm{pA}$. Similarly, we found that $\gamma-7$ increases kainate-evoked currents in transfected cells, to $\sim 2000$ pA (Fig. $3 A, D)$. Cotransfection of $\gamma-5$ yields a small but marginally significant increase in kainate-evoked currents (125 pA) (Fig. 3D). $\gamma-6$ has no effect on the kainate-evoked currents. We found $\gamma-2$ and $\gamma-7$ also greatly increase the efficacy of kainate on GluR1o receptors (Fig. $3 E$ ). By preferentially enhancing kainate-evoked currents, both $\gamma$-2 and $\gamma-7$ increase the AMPA receptor $I_{\text {kainate }} /$ $I_{\text {glutamate }}$ ratio (Fig. $3 F-I$ ). However, $\gamma$-2 has a much greater effect on $I_{\text {kainate }} / I_{\text {glutamate }}$ than does $\gamma$-7 (Fig. $3 H, I$ ).

Previous studies showed that $\gamma-2$ increases the potency of glutamate for GluR1 (Priel et al., 2005; Tomita et al., 2005b). Similarly, we find that cotransfection of $\gamma-2$ shifts the doseresponse curve for glutamate to the left and increases the $\mathrm{EC}_{50}$ by threefold. In contrast, transfectants containing $\gamma$-7 plus GluR1 showed similar $\mathrm{EC}_{50}$ as those containing GluR1 alone (Fig. 4A). The $\mathrm{EC}_{50}$ for kainate was not altered by $\gamma-2$ or $\gamma-7$ (Fig. $4 B$ ).

$\gamma$-2 slows both the deactivation and desensitization of associated AMPA receptors (Priel et al., 2005; Tomita et al., 2005b). To determine whether $\gamma-7$ also alters channel gating, we expressed pre-imm, preimmune serum.
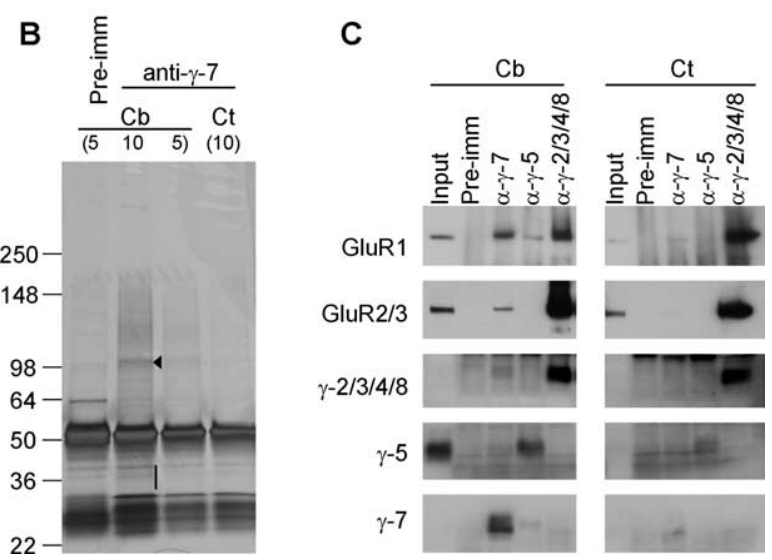

Figure 2. AMPA receptor subunits are the major binding partners for $\gamma-7 . \boldsymbol{A}, \boldsymbol{B}$, Solubilized cerebellar or cerebrocortica membranes were immunoprecipitated with antibodies to $\gamma-5(\boldsymbol{A})$ or $\gamma-7(\boldsymbol{B})$, and adherent proteins were analyzed by silver staining. We detected a specific band at $100 \mathrm{kDa}$ (arrowhead) in the $\gamma-7$ immunoprecipitate from the cerebellum. No specific were identified in $\gamma$-7 immunoprecipitates from the cortex or in $\gamma$-5-immunoprecipitates from either brain region. Mass

\begin{tabular}{|c|c|c|}
\hline Hits & Identified peptides & Identified protein \\
\hline 9 & $\begin{array}{l}\text { FALSQLTEPPK } \\
\text { FEGLTGNVQFNEK } \\
\text { VMAEAFQSLR } \\
\text { QTEIAYGTLEAGSTK } \\
\text { YTSALTYDGVK } \\
\text { GPVNLAVLK } \\
\text { VMAEAFQSLR } \\
\text { GYGIATPK } \\
\text { LSEQGVLDK }\end{array}$ & GluR1 \\
\hline 7 & $\begin{array}{l}\text { QTEIAYGTLDSGSTK } \\
\text { FAYLYDSDR } \\
\text { TPVNLAVLK } \\
\text { QVQVEGLSGNIK } \\
\text { GYGIATPK } \\
\text { SAEPSVFVR } \\
\text { LSEQGVLDK }\end{array}$ & GluR2 \\
\hline 5 & $\begin{array}{l}\text { QTEIAYGTLDSGSTK } \\
\text { TPVNLAVLK } \\
\text { LSEAGVLDK } \\
\text { EYPGSETPPK } \\
\text { LNEQGLLDK }\end{array}$ & GluR4 \\
\hline 3 & $\begin{array}{l}\text { QTEIAYGTLDSGSTK } \\
\text { FVYLYDTER } \\
\text { LNEQGLLDK }\end{array}$ & GluR3 \\
\hline
\end{tabular}

The $100 \mathrm{kDa}$ band that coimmunoprecipitated with $\gamma-7$ from the cerebellum was digested with trypsin, and peptides were identified by mass spectroscopy. "Hits" refer to the number of peptides detected. Only proteins with more than two hits are listed.

GluR1 alone and in the presence of $\gamma-2, \gamma$-5, or $\gamma$-7 in HEK293T cells (Fig. 5). Using ultra-fast application of glutamate to outsideout patches, we compared the effect of the three $\gamma$-subunits on deactivation after a $1 \mathrm{~ms}$ pulse of glutamate (Fig. $5 A, C$ ) and on desensitization during a $100 \mathrm{~ms}$ application of glutamate (Fig. $5 B, D) . \gamma-5$ had no effect on either deactivation or desensitization; however, $\gamma-7$ slowed both deactivation and desensitization to the same extent as did $\gamma$-2. 


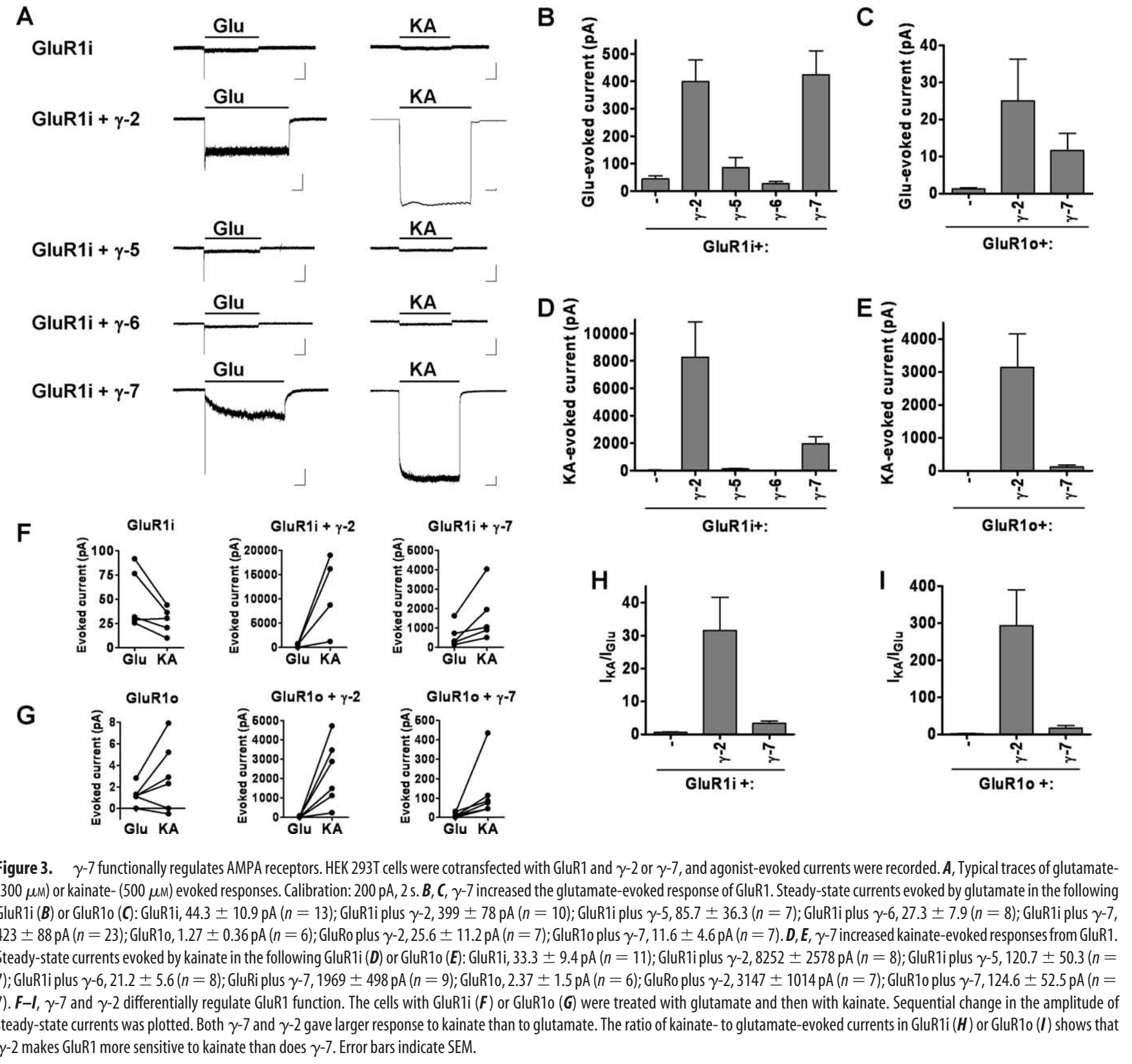

To determine whether $\gamma-7$ can regulate neuronal AMPA receptors, we transfected cultured granule cells from stargazer mice, which lack AMPA-mediated synaptic transmission and have very few surface AMPA receptors (Chen et al., 2000). In the presence of cyclothiazide to block desensitization, we examined whole-cell responses to glutamate or kainate (Fig. 6). In cells expressing only EGFP, neither the glutamate nor kainate responses are augmented above the minimal baseline. Expression of $\gamma-5$ depressed the glutamate response (Fig. $6 A, B$ ) but had no effect on the kainate response (Fig. $6 A, C$ ). In contrast, $\gamma$-7 increased the responses to both glutamate and kainate. The degree of rescue by $\gamma-7$ was, however, significantly less than that seen with $\gamma$-2 (Fig. 6). Why $\gamma-7$ is less effective than $\gamma-2$ in rescue of AMPA receptor function in stargazer granule cells is unclear. As granule cells express primarily GluR2 and GluR4, but not GluR1, it is possible that $\gamma-7$ preferentially traffics GluR1-containing receptors in neurons. As $\gamma-7$ is not enriched in cerebellar granule cells (see below), it may lack features of $\gamma-2$, which represents the functional TARP for these neurons (Chen et al., 1999; Hashimoto et al., 1999).

$\gamma-7$ is enriched in Purkinje cells and in cerebellar glomeruli To compare the expression of $\gamma-7$ and $\gamma-2 / 3 / 4 / 8$ at the cellular level with that of GluR1 and GluR2/3, we stained rat brain sections with each antibody. Low-power examination shows that $\gamma-7$ is enriched in the cerebellum (Fig. $7 A$ ), whereas the $\gamma-2 / 3 / 4 / 8$ antibody stains numerous brain regions (Fig. $7 B$ ), including the cerebellum, hippocampus, cerebral cortex, and corpus striatum. Similarly, antibodies to GluR1 or GluR2/3 discretely stain specific neuronal populations throughout the rat brain (Fig. $7 C, D$ ).

High-power magnification of the cerebellum shows that $\gamma-7$ occurs in the neuropil of the molecular layer, in Purkinje cells bodies, and in synaptic glomeruli of the granule cell layer (Fig. $7 E$ ). In situ hybridization of each TARP isoform done as part of the Allen Brain Atlas (Allen Institute for Brain Science, 2007; Lein et al., 2007) shows that $\gamma-7$ mRNA is expressed in cerebellar 

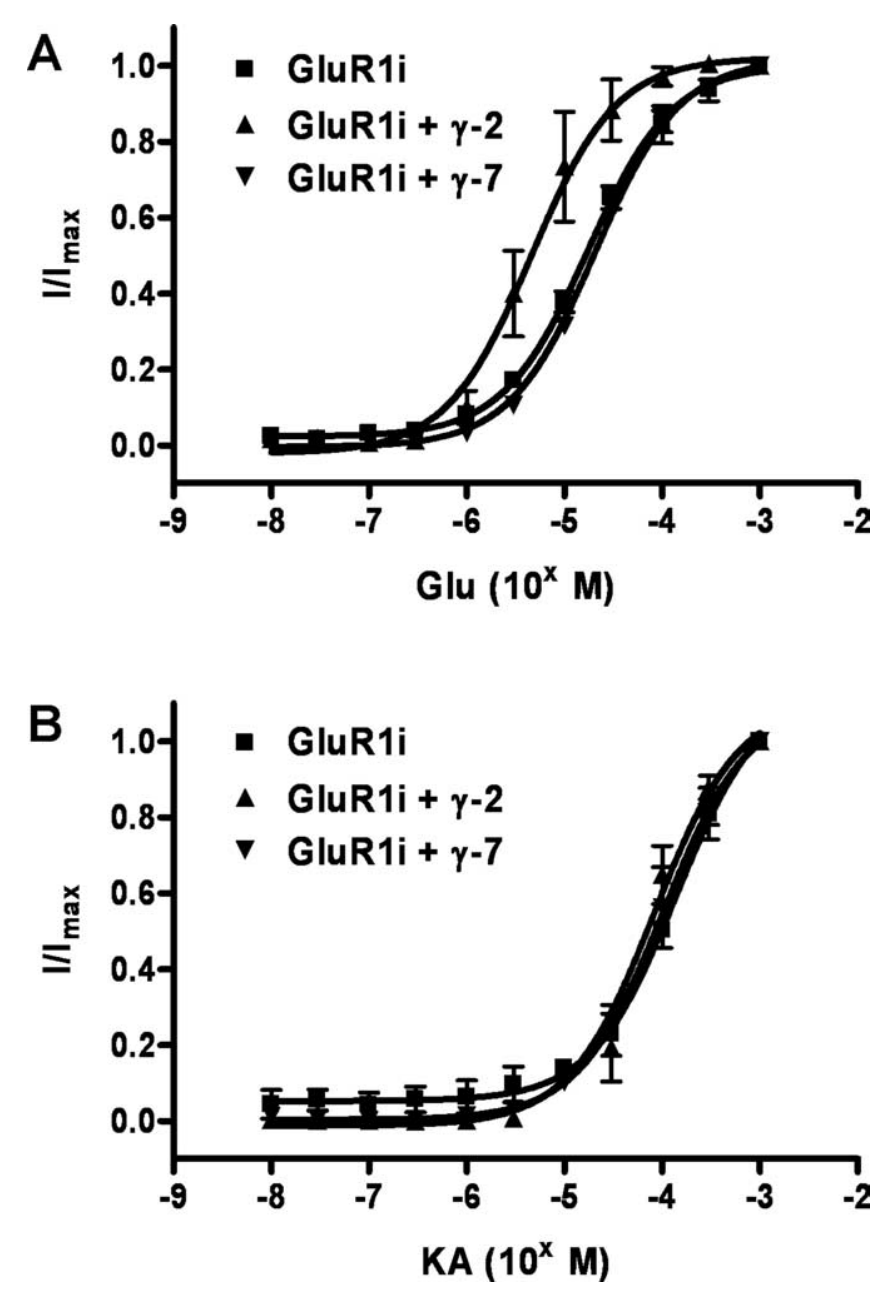

Figure 4. $\quad \gamma-2$, but not $\gamma-7$, lowers the $\mathrm{EC}_{50}$ for glutamate at GluR1i. Dose-response curve of glutamate- $(\boldsymbol{A})$ or kainate- (KA; $\boldsymbol{B})$ evoked currents in transfected $293 \mathrm{~T}$ cells. The steady-state currents evoked by varying concentrations of glutamate or kainate were measured and normalized to that evoked by $1 \mathrm{~mm}$ glutamate or kainate. Error bars indicate SEM.

Purkinje cells and in scattered cells of the granule cell layer that likely represent Golgi cells (supplemental Fig. 1, available at www.jneurosci.org as supplemental material). Together, the immunohistochemical and in situ hybridization studies of $\gamma$-7 suggest the protein occurs in dendritic/postsynaptic regions of Purkinje and Golgi neurons. Antibody to $\gamma-2 / 3 / 4 / 8$ stained cell bodies and neuropil in all layers of the cerebellum (Fig. $7 F$ ), and this fits with the mRNA expression of $\gamma$ - 2 in granule and Purkinje neurons and $\gamma-3$ in Golgi cells (supplemental Fig. 1, available at www.jneurosci.org as supplemental material). For comparison and as reported previously (Petralia and Wenthold, 1992), GluR1 occurs prominently in the molecular layer (Fig. 7G), and GluR2/3 stains neuropil in the molecular layer, Purkinje cell bodies, and glomerular synapses in the granule cell layer (Fig. $7 H$ ).

$\boldsymbol{\gamma}-7$ is enriched in the PSD and binds to PSD-95

GluRs and their associated scaffolding machinery occur in the PSD, a submembranous cytoskeletal specialization. To assess subcellular distribution of $\gamma-7$ and $\gamma-5$, we fractionated cerebellar homogenates. Western blotting of these fractions revealed that $\gamma-7$ is enriched in synaptosomes (Fig. 8A). Furthermore, $\gamma-7$ in synaptosomes resists extraction with Triton X-100 and therefore is concentrated in the PSD fractions. The subcellular distribution of $\gamma-7$ parallels that of $\gamma-2 / 3 / 4 / 8$, GluR1, and GluR2/3. On the
A

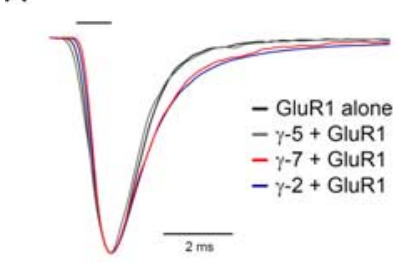

C

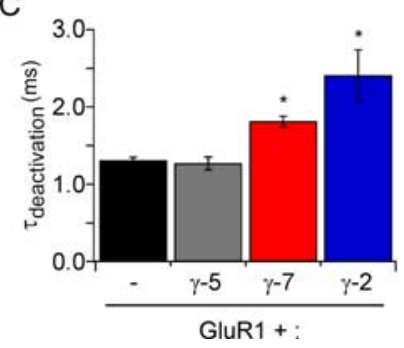

B

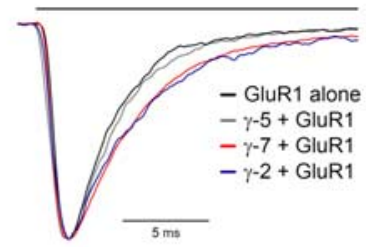

D

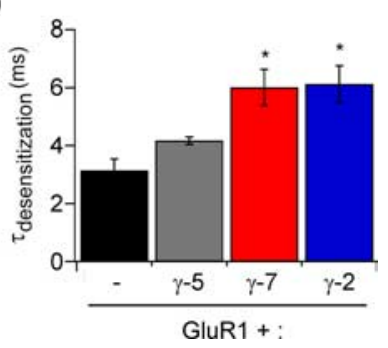

Figure 5. $\quad \gamma-7$, but not $\gamma-5$, slows deactivation and desensitization of GluR1 responses. HEK293T cells were transfected with GluR1i either alone or with $\gamma-5, \gamma-7$, or $\gamma-2$, and glutamate-evoked currents from outside-out patches were recorded. $A$, Superimposed typical responses to $1 \mathrm{~ms}(\boldsymbol{A})$ or $100 \mathrm{~ms}(\boldsymbol{B})$ applications of $1 \mathrm{~mm}$ glutamate. Responses were normalized to their peak amplitudes to compare their time courses. $\boldsymbol{C}, \gamma-7(n=8)$ and $\gamma-2(n=5)$ slowed deactivation of GluR1i $(n=5)(p<0.01)$, whereas $\gamma-5(n=3)$ did not. $\boldsymbol{D}, \gamma-7(n=5)$ and $\gamma$-2 slowed deactivation of GluR1i $(n=4)(p<0.01)$, whereas $\gamma-5(n=4)$ did not. Error bars indicate SEM. Asterisks indicate statistical significance with respect to GluR1i alone (unpaired Wilcoxon test with corrected $\alpha$ ).

contrary, $\gamma-5$ is enriched in microsomal fraction (P3) and synaptosomal fraction but not in the PSD. This observation is consistent with the report that $\gamma-5$ is mainly expressed in cerebellar Bergmann glia (Fukaya et al., 2005), which lack a PSD domain. As controls, we show that PSD-95 and synaptophysin are enriched in the PSD and synaptic vesicle fractions, respectively. As further evidence for distinct fractionation, we found that $\gamma-7$, but not $\gamma-5$, resists solubilization with 1 or $5 \%$ Triton X-100, a feature of PSD proteins (Fig. $8 \mathrm{~B}$ ).

Synaptic targeting of AMPA receptors requires interaction of associated TARPs with PSD-95 or related PDZ (PSD-95/Discs large/zona occludens-1) proteins (Elias et al., 2006). We therefore asked whether neuronal PSD-95 binds to $\gamma-5$ or $\gamma$-7. Immunoprecipitation of solubilized membranes showed that PSD-95 associated with $\gamma-7$ and $\gamma-2 / 3 / 4 / 8$ but not with $\gamma-5$ (Fig. $8 C$ ). Coimmunoprecipitation of PSD-95 with $\gamma-7$ was greater from cerebellar than from cerebrocortical membranes, consistent with the higher expression of $\gamma-7$ in the cerebellum. To determine whether the interaction of $\gamma-7$ with PSD-95 can occur in nonneuronal cells, we performed a similar analysis in transfected 293 T cells. We found that PSD-95 coimmunoprecipitated with $\gamma-2$ or $\gamma-7$ in cotransfected 293 T cells. We also found that $\gamma-5$ can bind to PSD-95 in heterologous cells. As control, we show that PSD-95 did not associate with $\gamma$-1 (Fig. 8C).

\section{Discussion}

This study defines $\gamma-7$ as a new member of the TARP family. Like other TARPs, $\gamma$-7 binds AMPA receptors tightly and selectively, traffics AMPA receptors to the membrane surface, and slows AMPA receptor deactivation and desensitization. However, compared with other TARPs, $\gamma-7$ differentially modulates the pharmacology of AMPA receptors for glutamate and kainate. The PSD enrichment of $\gamma-7$ and its expression in the cerebellum suggests roles for this novel TARP in regulating AMPA receptors in cerebellar neurons. 
A

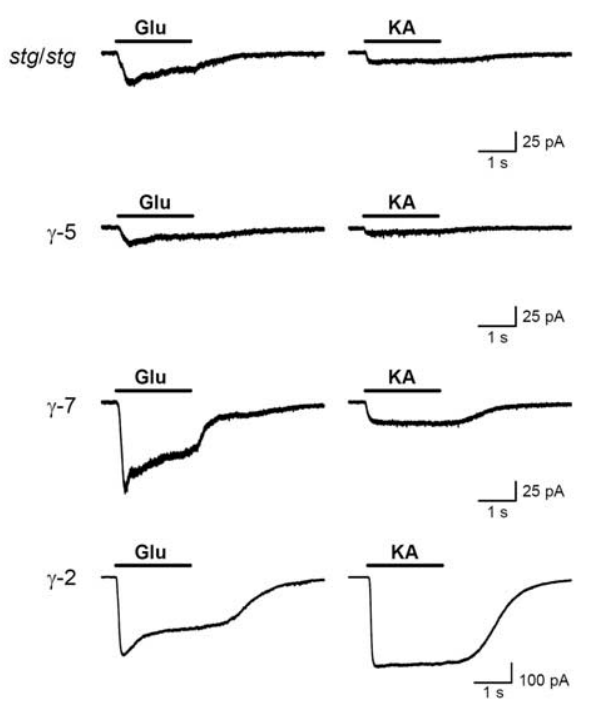

B

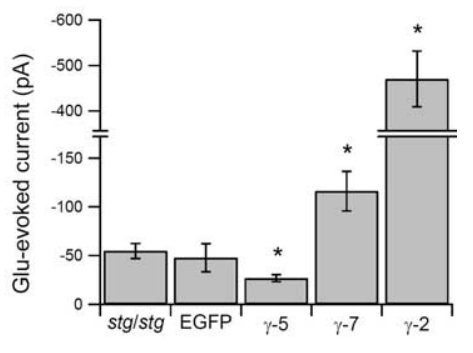

C

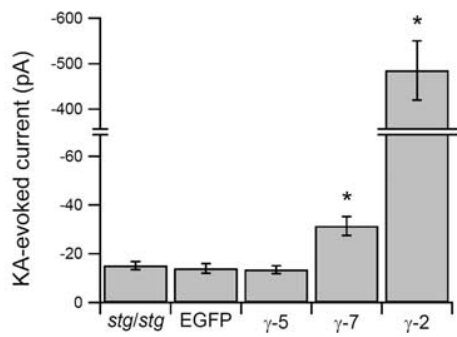

Figure 6. $\quad \gamma-7$, but not $\gamma$-5, rescued the surface expression of AMPA receptors in stargazer cerebellar granule cells. Cerebellar granule neurons from stg/stg mice were transfected with GFP, $\gamma-5, \gamma-7$, or $\gamma-2$, and agonist-evoked currents were recorded. $\boldsymbol{A}$, Typical traces of responses to $1 \mathrm{~mm}$ glutamate plus $100 \mu \mathrm{m}$ cyclothiazide or $1 \mathrm{~mm}$ kainate (KA). $\boldsymbol{B}, \boldsymbol{C}, \gamma-7(n=15)$ and $\gamma$-2 $(n=11)$ potentiated AMPA receptor responses to both glutamate $(p<0.005)$ and kainate $(p<0.0001)$ to different extents relative to untransfected $(n=15)$ or GFP $(n=12)$, whereas $\gamma-5(n=12)$ reduced responses to glutamate $(p<$ 0.002 ). Error bars indicate SEM. Asterisks indicate statistical significance with respect to untransfected (unpaired Wilcoxon test with corrected $\alpha$ ).

Our identification of $\gamma-7$ as a novel TARP is surprising because previous work in heterologous cells showed that $\gamma-5$, which is highly similar to $\gamma-7$, does not directly bind to AMPA receptors and does not regulate their function (Tomita et al., 2004). The role for $\gamma-5$ in the brain remains uncertain. We did detect a small and specific interaction of $\gamma-5$ with GluR1 in cerebellar extracts. The very high sequence identity of $\gamma-5$ with $\gamma-7$ would now seem to indicate a similar role for $\gamma-5$ in AMPA receptor trafficking and gating. However, we found no effects of $\gamma-5$ on AMPA receptors in non-neuronal cells or cerebellar granule cells. Perhaps the interaction of $\gamma-5$ with AMPA receptors requires additional factors that are not present in our transfected HEK cells, granule cells, or

in previously studied oocytes (Tomita et al., 2004). These additional factors may dissociate during membrane solubilization, which would explain the weak coimmunoprecipitation of AMPA receptors and $\gamma-5$ in the cerebellum. Alternatively, $\gamma-5$ may primarily modulate the function of other receptors. Future studies are needed to determine the functional roles for $\gamma-5$.

Compared with the other four TARP members, $\gamma-7$ shows the greatest sequence divergence. Importantly, all four previously identified TARPs contain the identical C-terminal sequence (-T-T-P-V $\left.{ }^{\star}\right)$, which mediates binding to PSD-95. The highly related $\mathrm{C}$ terminus of $\gamma$-7 (-T-S-P$C^{\star}$ ) differs only slightly from the canonical type I PDZ consensus binding sequence (Songyang et al., 1997). Indeed, previous studies of the human leutropin receptor have shown that a C-terminal cysteine residue can accommodate binding to type I PDZ domains (Hirakawa et al., 2003). Nevertheless, $\gamma$ - 7 binds to PSD-95 both in neurons and $\gamma-7$ cofractionates with AMPA receptors in the PSD fraction from the cerebellum.

Each TARP isoform shows a distinct neuronal pattern of distribution. Stargazin is enriched in the granule and Purkinje cells of the cerebellum, $\gamma-3$ is enriched in principle neurons of the cerebral cortex and in cerebellar Golgi cells, $\gamma-8$ is enriched in the hippocampus, and $\gamma-4$ is abundant in developing neurons throughout the neuroaxis and remains enriched in mature striatal neurons. The $\gamma-7$ protein is highly expressed in Purkinje cells of the cerebellum and in glomerular synapses in the granule cell layer of the cerebellum, where $\gamma-7$ appears to derive from cerebellar Golgi cells (supplemental Fig. 1, available at www.jneurosci.org as supplemental material). It is interesting to note that Purkinje cells abundantly express two

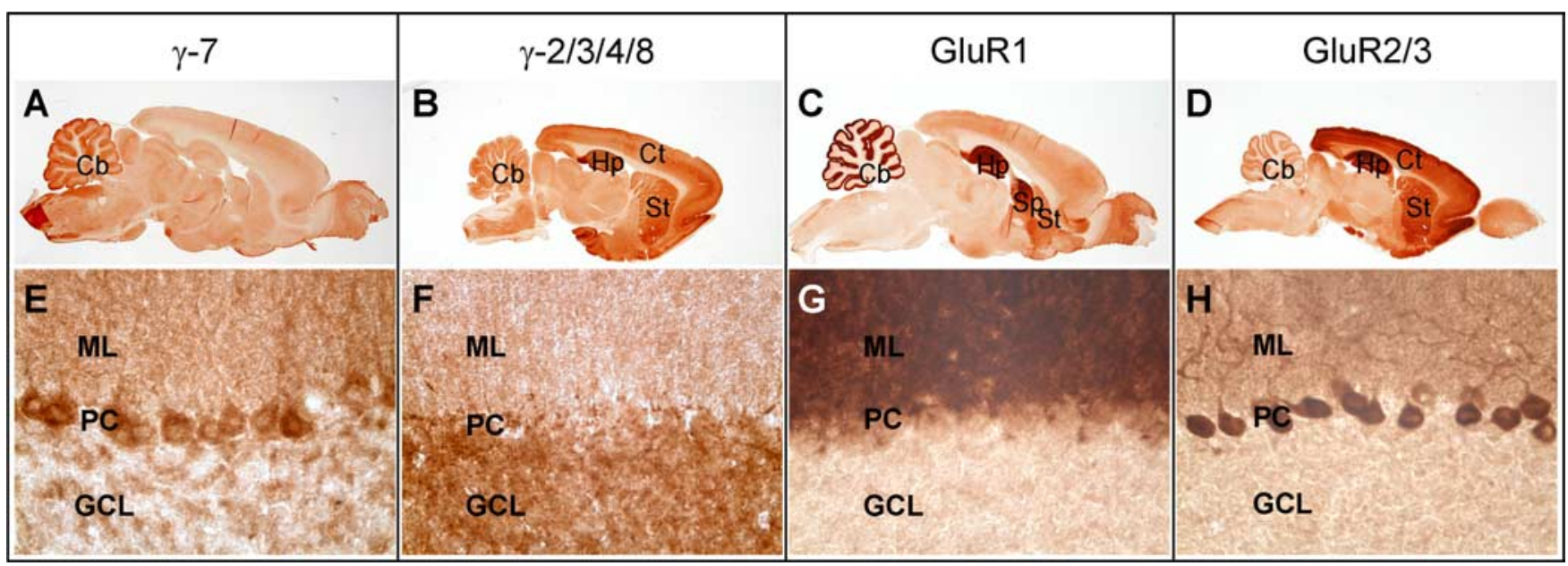

Figure 7. Differential localization of $\gamma-7$ and $\gamma-2 / 3 / 4 / 8$ in the brain. Sagittal brain sections were stained with antibodies to $\gamma-7(\boldsymbol{A}, \boldsymbol{E}), \gamma-2 / 3 / 4 / 8(\boldsymbol{B}, \boldsymbol{F}), \mathrm{GluR1}(\boldsymbol{C}, \boldsymbol{G})$, or GluR2 (D, H). $\gamma-7$ is enriched in the cerebellum $(\boldsymbol{A})$ and $\gamma-2 / 3 / 4 / 8$ stains numerous brain regions $(\boldsymbol{B})$. GluR1 and GluR2 both occur discretely in neuronal populations throughout in the brain $(\boldsymbol{C}, \boldsymbol{D})$. $\mathrm{Cb}$, cerebellum; $\mathrm{Ct}$, cerebral cortex; Hp, hippocampus; Sp, septum;St, striatum. $E$, High-power magnification shows $\gamma$-7 immunoreactivity in the somatodendritic regions of Purkinje cells and in glomeruli of the granule cell layer. $\boldsymbol{F}$, Antibody to $\gamma-2 / 3 / 4 / 8$ stained all layers in cerebellum. $\boldsymbol{G}$, GluR1 gave strong staining in molecular layer. $\boldsymbol{H}$, GluR2 showed strong signal in Purkinje cells and lesser staining in molecular and granule cell layers. ML, Molecular layer; PC, Purkinje cell; GCL, granule cell layer. 
TARP isoforms, stargazin and $\gamma-7$. However, we detect minimal coimmunoprecipitation of stargazin with $\gamma-7$, which indicates that AMPA receptors associate with only one TARP isoform. This segregation may allow TARPs to differentially modulate distinct classes of AMPA receptors within individual neurons. This would fit with previous studies in the hippocampus suggesting that $\gamma-8$ primarily traffics extrasynpatic AMPA receptors, whereas $\gamma-2$ traffics the synaptic receptors (Inamura et al., 2006).

We were struck by the preferential interaction of $\gamma-7$ with GluR1 relative to GluR2/3. In the cerebellum, the GluR1 band bound to $\gamma-7$ was far stronger than that of GluR2/3, whereas this ratio was reversed in the $\gamma-2 / 3 / 4 / 8$ immunoprecipitate. A similar preference for GluR1 was apparent in $\gamma-7$ immunoprecipitates from the cerebral cortex. This selectivity could reflect preferential binding of $\gamma-7$ to AMPA receptors lacking GluR2. However, in heterologous cells, we found that $\gamma-7$ effectively traffics homomeric GluR1, homomeric GluR2, and heteromeric GluR1/2 containing AMPA receptors (data not shown), which would argue against GluR-specific trafficking by $\gamma$-7. In addition, $\gamma-7$ rescued AMPA receptor surface expression in granule cells, which express GluR2 and GluR4 subunits. Future studies will need to explore the potential for GluR subunit-specific interactions with TARP isoforms.

Why is there such a large family of TARP isoforms? Throughout the brain, AMPA receptors show distinct biophysical characteristics. Much of this derives from the distinct expression pattern of GluR subunits, which influence AMPA receptor kinetics, gating, and ion permeability (Hollmann et al., 1991; Sommer et al., 1991). The discovery of TARP subunits suggests a role for these auxiliary subunits in dictating the unique properties of AMPA receptors in specific brain regions. That $\gamma-7$ differentially regulates AMPA receptor glutamate affinity and kainate efficacy may explain some of the regional variations noted in AMPA receptor pharmacology (Porter and Greenamyre, 1994; Fleck et al., 1996). Future studies are needed to define the regulatory functions of distinct TARPs and how they sculpt excitatory transmission throughout the brain.

The phenotypes of TARP mutant mice emphasize the neuronspecific roles and redundancies of TARP isoforms. Stargazer mice lack $\gamma-2$ and show loss of AMPA receptor function in cerebellar granule cells, which are neurons that do not express other TARP isoforms. Mice lacking $\gamma-8$ have an $80-90 \%$ decrease in extrasynaptic AMPA receptor in hippocampal neurons (Rouach et al., 2005; Fukaya et al., 2006). The residual AMPA receptor function in the hippocampus of $\gamma-8$ knockouts likely reflects expression of $\gamma-2$ and $\gamma-3$ in these neurons (Fukaya et al., 2005). The finding that AMPA receptor responses are present in cerebellar Purkinje cells of stargazer mice has been perplexing because only $\gamma-2$, and not $\gamma-3, \gamma-4$ or $\gamma-8$, occurs in these neurons (Fukaya et al., 2005). Our identification of $\gamma-7$ as a new TARP enriched in Purkinje cells likely explains this functional redundancy and the presence of AMPA receptor function in Purkinje cells of stargazer mice.

These studies expand the family of TARPs and their general role in trafficking AMPA receptors. Recent studies have shown that stargazin-like molecules occur in worms and flies, and these proteins are critical for the activity of AMPA receptor gene products in these invertebrates (Walker et al., 2006). TARPs in all organisms selectively regulate AMPA-type GluRs and do not modulate other receptors or channels. Future studies are needed to determine whether NMDA-type GluRs or other neurotransmitterregulated ion channels also require auxiliary subunits.

\section{References}

Allen Institute for Brain Science (2007) Allen Brain Atlas. Retrieved April 18, 2007, from: http://www.brainmap.org.

Bedoukian MA, Weeks AM, Partin KM (2006) Different domains of the AMPA receptor direct stargazin-mediated trafficking and stargazinmediated modulation of kinetics. J Biol Chem 281:23908-23921.

Burgess DL, Gefrides LA, Foreman PJ, Noebels JL (2001) A cluster of three novel Ca2 + channel gamma subunit genes on chromosome 19q13.4: evolution and expression profile of the gamma subunit gene family. Genomics 71:339-350.

Chen L, Bao S, Qiao X, Thompson RF (1999) Impaired cerebellar synapse maturation in waggler, a mutant mouse with a disrupted neuronal calcium channel gamma subunit. Proc Natl Acad Sci USA 96:12132-12137.

Chen L, El-Husseini A, Tomita S, Bredt DS, Nicoll RA (2003) Stargazin differentially controls the trafficking of alpha-amino-3-hydroxyl-5methyl-4-isoxazolepropionate and kainate receptors. Mol Pharmacol 64:703-706.

Chen L, Chetkovich DM, Petralia RS, Sweeney NT, Kawasaki Y, Wenthold RJ, Bredt DS, Nicoll RA (2000) Stargazin regulates synaptic targeting of AMPA receptors by two distinct mechanisms. Nature 408:936-943. 
Chu PJ, Robertson HM, Best PM (2001) Calcium channel gamma subunits provide insights into the evolution of this gene family. Gene 280:37-48.

El-Husseini AE, Schnell E, Chetkovich DM, Nicoll RA, Bredt DS (2000) PSD-95 involvement in maturation of excitatory synapses. Science 290:1364-1368.

Elias GM, Funke L, Stein V, Grant SG, Bredt DS, Nicoll RA (2006) Synapsespecific and developmentally regulated targeting of AMPA receptors by a family of MAGUK scaffolding proteins. Neuron 52:307-320.

Fleck MW, Bahring R, Patneau DK, Mayer ML (1996) AMPA receptor heterogeneity in rat hippocampal neurons revealed by differential sensitivity to cyclothiazide. J Neurophysiol 75:2322-2333.

Fukaya M, Yamazaki M, Sakimura K, Watanabe M (2005) Spatial diversity in gene expression for VDCCgamma subunit family in developing and adult mouse brains. Neurosci Res 53:376-383.

Fukaya M, Tsujita M, Yamazaki M, Kushiya E, Abe K, Natsume R, Kano M, Kamiya H, Watanabe M, Sakimura K (2006) Abundant distribution of TARP gamma-8 in synaptic and extrasynaptic surface of hippocampal neurons and its major role in AMPA receptor expression on spines and dendrites. Eur J Neurosci 24:2177-2190.

Hale JE, Butler JP, Gelfanova V, You JS, Knierman MD (2004) A simplified procedure for the reduction and alkylation of cysteine residues in proteins prior to proteolytic digestion and mass spectral analysis. Anal Biochem 333:174-181.

Hashimoto K, Fukaya M, Qiao X, Sakimura K, Watanabe M, Kano M (1999) Impairment of AMPA receptor function in cerebellar granule cells of ataxic mutant mouse stargazer. J Neurosci 19:6027-6036.

Hirakawa T, Galet C, Kishi M, Ascoli M (2003) GIPC binds to the human lutropin receptor (hLHR) through an unusual PDZ domain binding motif, and it regulates the sorting of the internalized human choriogonadotropin and the density of cell surface hLHR. J Biol Chem 278:49348-49357.

Hollmann M, Heinemann S (1994) Cloned glutamate receptors. Annu Rev Neurosci 17:31-108.

Hollmann M, Hartley M, Heinemann S (1991) Ca2+ permeability of KAAMPA-gated glutamate receptor channels depends on subunit composition. Science 252:851-853.

Inamura $\mathrm{M}$, Itakura $\mathrm{M}$, Okamoto $\mathrm{H}$, Hoka $\mathrm{S}$, Mizoguchi $\mathrm{A}$, Fukazawa $\mathrm{Y}$, Shigemoto R, Yamamori S, Takahashi M (2006) Differential localization and regulation of stargazin-like protein, gamma- 8 and stargazin in the plasma membrane of hippocampal and cortical neurons. Neurosci Res 55:45-53.

Jo K, Derin R, Li M, Bredt DS (1999) Characterization of MALS/Velis-1, -2, and -3: a family of mammalian LIN-7 homologs enriched at brain synapses in association with the postsynaptic density-95/NMDA receptor postsynaptic complex. J Neurosci 19:4189-4199.

Jonas P, Sakmann B (1992) Glutamate receptor channels in isolated patches from CA1 and CA3 pyramidal cells of rat hippocampal slices. J Physiol (Lond) 455:143-171.

Kiskin NI, Krishtal OA, Tsyndrenko A (1986) Excitatory amino acid receptors in hippocampal neurons: kainate fails to desensitize them. Neurosci Lett 63:225-230.

Klugbauer N, Dai S, Specht V, Lacinová L, Marais E, Bohn G, Hofmann F (2000) A family of gamma-like calcium channel subunits. FEBS Lett 470:189-197.

Lein ES, Hawrylycz MJ, Ao N, Ayres M, Bensinger A, Bernard A, Boe AF, Boguski MS, Brockway KS, Byrnes EJ, Chen L, Chen L, Chen TM, Chin MC, Chong J, Crook BE, Czaplinska A, Dang CN, Datta S, Dee NR, et al. (2007) Genome-wide atlas of gene expression in the adult mouse brain. Nature 445:168-176.

Letts VA, Felix R, Biddlecome GH, Arikkath J, Mahaffey CL, Valenzuela A, Bartlett II FS, Mori Y, Campbell KP, Frankel WN (1998) The mouse stargazer gene encodes a neuronal Ca2+-channel gamma subunit. Nat Genet 19:340-347.

Losi G, Prybylowski K, Fu Z, Luo J, Wenthold RJ, Vicini S (2003) PSD-95 regulates NMDA receptors in developing cerebellar granule neurons of the rat. J Physiol (Lond) 548:21-29.

Moss FJ, Viard P, Davies A, Bertaso F, Page KM, Graham A, Canti C, Plumpton M, Plumpton C, Clare JJ, Dolphin AC (2002) The novel product of a five-exon stargazin-related gene abolishes $\mathrm{Ca}(\mathrm{V}) 2.2$ calcium channel expression. EMBO J 21:1514-1523.

Nakagawa T, Cheng Y, Ramm E, Sheng M, Walz T (2005) Structure and different conformational states of native AMPA receptor complexes. Nature 433:545-549.
Nicoll RA, Tomita S, Bredt DS (2006) Auxiliary subunits assist AMPA-type glutamate receptors. Science 311:1253-1256.

Noebels JL, Qiao X, Bronson RT, Spencer C, Davisson MT (1990) Stargazer: a new neurological mutant on chromosome 15 in the mouse with prolonged cortical seizures. Epilepsy Res 7:129-135.

Petralia RS, Wenthold RJ (1992) Light and electron immunocytochemical localization of AMPA-selective glutamate receptors in the rat brain. J Comp Neurol 318:329-354.

Porter RH, Greenamyre JT (1994) Regional variations in the pharmacology of AMPA receptors as revealed by receptor autoradiography. Brain Res 664:202-206.

Priel A, Kolleker A, Ayalon G, Gillor M, Osten P, Stern-Bach Y (2005) Stargazin reduces desensitization and slows deactivation of the AMPA-type glutamate receptors. J Neurosci 25:2682-2686.

Rouach N, Byrd K, Petralia RS, Elias GM, Adesnik H, Tomita S, Karimzadegan S, Kealey C, Bredt DS, Nicoll RA (2005) TARP gamma-8 controls hippocampal AMPA receptor number, distribution and synaptic plasticity. Nat Neurosci 8:1525-1533.

Schnell E, Sizemore M, Karimzadegan S, Chen L, Bredt DS, Nicoll RA (2002) Direct interactions between PSD-95 and stargazin control synaptic AMPA receptor number. Proc Natl Acad Sci USA 99:13902-13907.

Seeburg PH (1993) The TINS/TIPS Lecture. The molecular biology of mammalian glutamate receptor channels. Trends Neurosci 16:359-365.

Shevchenko A, Wilm M, Vorm O, Mann M (1996) Mass spectrometric sequencing of proteins silver-stained polyacrylamide gels. Anal Chem 68:850-858.

Sommer B, Keinanen K, Verdoorn TA, Wisden W, Burnashev N, Herb A, Kohler M, Takagi T, Sakmann B, Seeburg PH (1990) Flip and flop: a cell-specific functional switch in glutamate-operated channels of the CNS. Science 249:1580-1585.

Sommer B, Kohler M, Sprengel R, Seeburg PH (1991) RNA editing in brain controls a determinant of ion flow in glutamate-gated channels. Cell 67:11-19.

Songyang Z, Fanning AS, Fu C, Xu J, Marfatia SM, Chishti AH, Crompton A, Chan AC, Anderson JM, Cantley LC (1997) Recognition of unique carboxyl-terminal motifs by distinct PDZ domains. Science 275:73-77.

Sumner LW, Wolf-Sumner B, White SP, Asirvatham VS (2002) Silver stain removal using $\mathrm{H} 2 \mathrm{O} 2$ for enhanced peptide mass mapping by matrixassisted laser desorption/ionization time-of-flight mass spectrometry. Rapid Commun Mass Spectrom 16:160-168.

Tomita S, Chen L, Kawasaki Y, Petralia RS, Wenthold RJ, Nicoll RA, Bredt DS (2003) Functional studies and distribution define a family of transmembrane AMPA receptor regulatory proteins. J Cell Biol 161:805-816.

Tomita S, Fukata M, Nicoll RA, Bredt DS (2004) Dynamic interaction of stargazin-like TARPs with cycling AMPA receptors at synapses. Science 303:1508-1511.

Tomita S, Stein V, Stocker TJ, Nicoll RA, Bredt DS (2005a) Bidirectional synaptic plasticity regulated by phosphorylation of stargazin-like TARPs. Neuron 45:269-277.

Tomita S, Adesnik H, Sekiguchi M, Zhang W, Wada K, Howe JR, Nicoll RA, Bredt DS (2005b) Stargazin modulates AMPA receptor gating and trafficking by distinct domains. Nature 435:1052-1058.

Tomita S, Sekiguchi M, Wada K, Nicoll RA, Bredt DS (2006a) Stargazin controls the pharmacology of AMPA receptor potentiators. Proc Natl Acad Sci USA 103:10064-10067.

Tomita S, Shenoy A, Fukata Y, Nicoll RA, Bredt DS (2006b) Stargazin interacts functionally with the AMPA receptor glutamate-binding module. Neuropharmacology.

Tong G, Jahr CE (1994) Multivesicular release from excitatory synapses of cultured hippocampal neurons. Neuron 12:51-59.

Turetsky D, Garringer E, Patneau DK (2005) Stargazin modulates native AMPA receptor functional properties by two distinct mechanisms. J Neurosci 25:7438-7448.

Vandenberghe W, Nicoll RA, Bredt DS (2005) Stargazin is an AMPA receptor auxiliary subunit. Proc Natl Acad Sci USA 102:485-490.

Walker CS, Brockie PJ, Madsen DM, Francis MM, Zheng Y, Koduri S, Mellem JE, Strutz-Seebohm N, Maricq AV (2006) Reconstitution of invertebrate glutamate receptor function depends on stargazin-like proteins. Proc Natl Acad Sci USA 103:10781-10786.

Yamazaki M, Ohno-Shosaku T, Fukaya M, Kano M, Watanabe M, Sakimura $\mathrm{K}$ (2004) A novel action of stargazin as an enhancer of AMPA receptor activity. Neurosci Res 50:369-374.

Zhang W, Robert A, Vogensen SB, Howe JR (2006) The relationship between agonist potency and AMPA receptor kinetics. Biophys J 91:1336-1346. 